Slobodan Vuković Institute of Social Sciences

Belgrade
UDK: 323.232

Original Scientific Paper

Received: 24. 3. 2009.

\title{
THE MEDIA AND OFFICIALS - A NEGATIVE SYMBIOSIS DURING THE YUGOSLAVIA CRISIS OF THE 1990S
}

In this article author gives analysis of paradigm enforced through western media on the crisis and desintegration of Yugoslavia. By the aid of comparative analysis mutual influence is demonstrated between official's pronouncements and media informing. Along with the deepening of crisis one could notice daily grow of accusation of Serbs in number writen with aim to portray them as morally Evil. Therefore, Serbs for many officials were simply pigs and trash, or they were dumb-ass criminals, and at last they were the nation without law or any set of beliefs. Thereafter they were accused for terrorism and nazism, with threats that they must be brought to their knees begging for mercy, and finally that Serbia deserves to be turned into dust and ashes.

The role of all these accusations and threats was to justify disintegration of second Yugoslavia, and to minimize the role of western alies in this operation. In the very operation one could notice wide consensus between political and media elites in the West. Accusation of Serbs was question of prestige - and due to this fact some officials were rewarded with higher official positions while some journalists were given a remarkable prizes.

Key words: Serbs, Serbia, West, Media, Officials, qualifications, threats.

From the very beginning of the crisis in Yugoslavia to the present day (the question of Kosovo and Metohia and its recognition by the most powerful Western countries allied in NATO), several Western countries have played a crucial role in provoking and "managing" the crisis. And the more they managed it the worse the conflagration became. This is why their leaders, political and media elites (with the unstinting aid of cultural elites in Germany and Austria and, to a large extent, France, then later the entire west), whether they like to admit it or not, imposed their own view of events on public discourse in order to disguise their involvement. Their actions at the time, and subsequently, contributed substantially to the escalation of the crisis, and this makes them responsible for the events that followed on the territory of the second Yugoslavia in the last decade of the $20^{\text {th }}$ century. Simply put, it shall be demonstrated below that there is deep co-dependence and mutual influence between the statements of the highest officials, the reporting of the influential media and the actions of governments.

Germany and Austria played a leading role in this process until the recognition of Slovenia and Croatia, just as they had before when it came to south-eastern Europe (at the end of the $19^{\text {th }}$ and the beginning of the $20^{\text {th }}$ centuries). Great Britain and France joined them in return for insignificant concessions (referred to else- 
S. Vukovic, Media and Officials - A Negative Simbiosis during the Yugoslav Crisis in the 1990s

where $^{1}$ ), but primarily to shore up endangered European unity. After the recognition of Bosnia and Herzegovina, the role of crisis manager in Yugoslavia was taken over by the United States, with the full support of Germany, Great Britain, France, and Italy and, in almost all situations concerning the Serbs - the inevitable Vatican. The other countries gathered together in NATO were simply necessary allies or embellishment - some were pressured into acting as they did, others sought to prove their loyalty and allegiance to Washington or Bonn. The highest ranked American and European officials set the basic tone in demonizing Serbia and the Serbs by taking one side in their statements, militant rhetoric, and public hypocrisy and by acting in the Yugoslav disputes and subsequently in the conflicts. American and European mass media merely put this into effect, and the western officials sought to adjust the reports from the territory of second Yugoslavia to their own interests and turn them into pure propaganda for the purpose of gaining public support for their actions - in which they personally participated.

Let us start from the beginning. At the time he was the chancellor of Germany, Helmut Kohl referred to Serbia when advocating the "destruction of the last oasis of communism" in Europe. ${ }^{2}$ Klaus Kinkel, the minister of foreign affairs of Germany, advocated the punishment of Serbia from the very beginning - on May 24, 1992 he claimed straightforwardly that "Serbia must be brought to its knees". This is actually a mere reiteration of the statements of Austrian general Conrad von Hötzendorf and the German field marshal, general Colmar von Der Goltz from 1914, that "it is primarily necessary to throw Serbia to the ground". ${ }^{4}$ Adolf Hitler made a similar statement - even after the German fiasco at Stalingrad and the fall of Mussolini, he gave instructions that "Serbia should remain subdued and weak", claims Horstenau. ${ }^{5}$ Soon afterwards (on August 19, 1992), Kinkel raised the tone and introduced new, incriminating elements against the Serbs: "The attempt of the Serbian aggressors to perform an action of ethnic cleansing aimed against other ethnic groups, in order to achieve their national goals in Bosnia and Herzegovina, is genocide". ${ }^{6}$ Six months earlier, Francesco Kosiga, another member of the BonnRome axis renewed for this occasion, declared the same: "Serbia and the YNA are

\footnotetext{
${ }^{1}$ It is referred to in an unpublished paper on the influence of western governments and their diplomatic and military actions on the break-up/dissolution of the second Yugoslavia.

${ }^{2}$ Ranković. M (1994) „Raspad socijalističkih društvenih sistema u Evropi“, Sociološki pregled, Vol. 28, No. 2, p. 142 (http://www. socioloskipregled.org.rs)

${ }^{3}$ Süddeutsche Zeitung, 25 May 1992; also: Petrović Piroćanac, Z. (1999), Izbrisati srpski virus. Mala enciklopedija rasizma i šovinizma na kraju milenijuma, Jugoistok, Belgrade, p. 22

${ }^{4}$ Mitrović, A. (1981), Prodor na Balkan, Nolit, Belgrade, p. 233, 237

${ }^{5}$ Horstenau, G. E. (2007), Između Hitlera i Pavelića, Nolit, Belgrade, p. 274 [Broucek, Peter (1980-88), Ein General im Zwielicht, Die Erinnerungen Edmund Glaises von Horstenau, Böhlau, Wien]

${ }^{6}$ Džonston, D. (2005), Suludi krstaši, IGAM, Belgrade, p. 137 [Johnstone, D. (2002), Fools' Crusade, Montly Review Press, New York \& Pluto Press, London]
} 
conducting genocide". ${ }^{7}$ However, Richard Holbrook, an American diplomat, was forced to admit, upon being confronted with the facts, that banishing the Serbs from Krajina was "involuntary banishment"! Simultaneously, the American ambassador in Zagreb, Peter Galbraith, who played a significant role in the massacre and exodus of the Serbs from Krajina, claimed, in order to diminish the importance, not only of his personal participation, but also that of his government, that "the exodus of the Serbs was not ethnic cleansing" ${ }^{\prime \prime}$ Doris Pack, an EMP for the German CDU, declared before the European Parliament on February 18, 1993 that the Serbian aggression was based on the plan in which "raping women and castrating men was a part of the military arsenal of the Serbian aggressors". .

Then, after the recognition of Croatia, Slovenia and Bosnia and Herzegovina, and particularly during the NATO aggression against Yugoslavia, this array of attributes, of militant rhetoric and direct threats was expanded daily. Here are several typical descriptions, to illustrate the point. The president of the United States of America, William J. Clinton, declared that Serbia is "the heart of European darkness, the region where mosques are bombed, men and children killed and girls raped". ${ }^{10}$ Threats made by the world powers resemble those that Germany (and Austria) issued to Serbia before World War I and to Yugoslavia before World War II. Thus, Clinton declared that "the Serbs shall pay dearly for this"; US secretary of state, Madeleine Albright, declared that "the Serbs will be down on their knees begging for mercy", while the commander of NATO in Europe, Wesley Clark, said that "Serbia will be turned into dust and ashes". ${ }^{11}$ To corroborate all this, the propaganda war does not refrain from producing the most absurd falsehoods. Consequently, Javier Solana, then secretary general of NATO, told the BBC during the bombing of the FR Yugoslavia, that "men from the age of 30 to 60 can no longer be seen" in Kosovo. ${ }^{12}$ Soon afterwards, at the time FR Yugoslavia was breaking up, Solana spoke of friendship with the Serbian people, only to follow that by strongly supporting the independence of Montenegro and later that of Kosovo and Metohija. And, the German minister of defence at the time, Rudolph Scharping, spoke on several occasions of the Serbian concentration camps in Priština, and then he said that "the Kosovo genocide is not in preparation but is

\footnotetext{
${ }^{7}$ Политика, December 9, 1991

${ }^{8}$ Herman, S. E. (2006), „The Approved Narrative of Srebrenica Massacre“,International Journal for the Semiotics of Law, Vol. 19, No. 4, pp. 427-428

${ }^{9}$ Džonston, D. (2005), Suludi krstaši, IGAM, Beograd, p. 151 [Johnstone, D. (2002), Fools' Crusade, Montly Review Press, New York \& Pluto Press, London]

${ }^{10}$ The New York Times, May 23, 1999; published in: Srbija i NATO II (1999), special edition, Nova srpska politička misao, Belgrade, p. 24

11 "Metoda: rasturi, opustoši, uništi", Политика, Мау 25, 1999

${ }^{12}$ Vreme, November 20, 1999
} 
S. Vukovic, Media and Officials - A Negative Simbiosis during the Yugoslav Crisis in the 1990s

ongoing" $"$; this would soon turn into a mass grave, so as to justify the NATO aggression. Moreover, in order to justify the bombing, Scharping declared on March 28, 1999 on the first channel of the German television ARD, in the programme "Christiansen", that 30, 000 people were killed in Srebrenica. ${ }^{14}$ Scharping did not stop at such fabrications and allegations - thus, according to him, "the Serbs gathered 28 teachers in the village of Goden on March 27 and hanged them... In Veliki Alas, paramilitary troops killed 22 people on April 19, 1999. Heads were cut off many dead bodies. Others were disembowelled."15 Naturally, all this was a downright lie, as in many other instances, one traditionally wellaccepted by the officials and media in Germany because it concerned the Serbs. In other words, such public statements of German officials perpetuated the old and filled out new stereotypes. On February 31, 1999 Madeleine Albright, American secretary of state, confirmed on French television Europe I Scharping's statement that "there is a concentration camp in Kosovo with 20,000 Albanians in it, mostly women and children". ${ }^{16}$ At the same time, the State Department declared that 500,000 Albanians were presumed missing. On May 16, William Cohen, US secretary of state, declared that 100,000 Albanians of military age had gone missing, and that they may have been killed by the Serbs, ${ }^{17}$ while David Shefer, Madeleine Albright's press representative, declared on April 18 that he was concerned because 225,000 people were missing without a trace. ${ }^{18}$ The Viennese Der Standard (on April 7, 1999) went a step further in reporting on the Serbian massacre in Kosovo and Metohia - "An unbridled soldatesque wreaked havoc for three months... 800,000 people were killed in a virtual bloodbath". ${ }^{19}$ While Care Short, a minister in the British government, said that the "shameful" critics of the Kosovo war were "the equivalent of those approving Hitler". ${ }^{20}$ All these statements of the Euro-American officials were broadcast, without reserve, by practically all main

${ }^{13}$ Elzeser, J. (2002), Ratni zločini.Bestidne laži $i$ žrtve NATO-a u kosovskom sukobu, Jasen, Nikšić, p. 86-92 [Elässer, J. (2001), Kriegsverbrechen. Die tödlichen Lügen der Nato und ihre Opfer im Kosovo-Konflikt, Konkret, Hamburg]

${ }^{14}$ Elzeser, J. (2002), [Ratni zločini], p. 13

${ }^{15}$ APA/DPA, No. 21, May 30, 1999; according to: Olševski, M. (2001), Rat za Kosovo: novi boj Srbije na Kosovu, Prometej, Novi Sad, p. 200 [Olschewski, M. (1999), Der Krieg am Kosovo: Serbiens neue Sclacht am Amselfeld, Nidda Verlag GmbH]

${ }^{16}$ Elzeser, J. (2002), [Ratni zločini], p. 87

${ }^{17}$ New York Times, November 11, 1999

${ }^{18}$ Džonston, D. (2005), [Suludi krstaši], p. 316

${ }^{19}$ Elzeser, J. (2002), [Ratni zločini], p. 89-90

${ }^{20}$ Hjum, M. (2001), „Nacifikovanje Srba, od bosne do Kosova“, in: Degradirana moć: mediji i kosovska kriza, prir: F. Hemond i E. Herman, Plato, Beograd, p. 129 [Hammond, F. and Herman, S. E. (2000), Degraded Capability: The Media and the Kosovo Krisis, Pluto Press, London] 
media networks. Naturally, after the discourse was thus established, a series of actions by the officials followed.

At the same time, Tony Blair, one of the most ardent advocates of the bombing of Serbia in 1999 and of sending ground forces to invade it, and subsequently a supporter of an independent Kosovo, declared that the bombing was "not only a military conflict", but "a battle between good and evil, between civilization and barbarity". ${ }^{21}$ Naturally, the Serbs were the Barbarians and the Evil, and NATO airplanes with cluster bombs and bombs containing depleted uranium were the morally Good and the civilization - a belief which the Western officials vehemently defend to this very day, claiming as trenchantly now as they did before, that the Serbs are sick with nationalism, and that they are stray sheep who need to be treated with aversion therapy against their will and onto whom the western value system needs to be imposed. This is precisely the belief which results in all the pressure which is daily imposed on Serbia with the help of participants within the country who seek to keep the (undeserved) positions they occupy, political power and the profits of corruption; ${ }^{22}$ they even tamper with parliamentary elections.

During the military actions in Bosnia and Herzegovina, and for years after the war, it was claimed that 200 thousand people were killed (information produced by the American CIA for the purposes of propaganda), while on another occasion it was claimed that it was 250 thousand mostly Muslim people; a claim which most in the West, Muslim officials, media, and independent "experts" uphold to this very day ${ }^{23}$. The fact that seemingly serious studies uphold this paradigm proves the extent to which it has become dominant. ${ }^{24}$ It is primarily based on prejudice, and on the widespread myth about the high moral qualities of Western journalism, which are given credit to. Contrary to the facts proving that the paradigm about the events in the second Yugoslavia is essentially based on a slippery slope of lies, which only achieved the snowball effect with time, i.e. the threshold of truth

${ }^{21}$ Sunday Telegraph, April 4, 1999. Blair generously offered 50,000 soldiers (half of the British army) for a land intervention against Serbia - Koreli Bernet, "'Prava stvar' je donela smrt”, Политика, Мау 8, 2007; taken from: The Independent, May 6, 2007

${ }^{22}$ See: Vuković, S. (2003), Korupcija i vladavina prava, IDN-Draganić, Belgrade; Vuković, S. (2005), Pravo, moral i korupcija,IDN-,,Filip Višnjić“, Belgrade

${ }^{23}$ Increasing the numbers of the victims of the war in Bosnia and Herzegovina multiply has shifted from propaganda rhetoric to ,scientific” publications. Thus, for instance, Mary Kaldor claims that there were 260,000 victims in it - Kaldor, M. (2005), Novi stari ratovi organizovano nasilje u globalizovanoj eri, Beorgadski krug, Belgrade, p. 57 [Kaldor, M. (2001), New \& Old Wars - organized violence in a global era, Polity Press, Cambridge]

${ }^{24}$ Mark R. Amstutz states without reserve in the introduction to his study on international ethics, that 250,000 people were killed in Bosnia and Herzegovina - Amstuc, R. M. (2008), Međunarodna etika: globalna politika:pojmovi, teorije i slučajevi, Službeni glasnik, Belgrade, p. 13 [Amstutz, R. M. (2008), International ethics. Concepts, theories and cases in global politics, Rowman \& Litlefield Publishers, Lanham, Maryland] 
S. Vukovic, Media and Officials - A Negative Simbiosis during the Yugoslav Crisis in the 1990s

became lower with each subsiquent case. Many examples prove this, among which is the statement of the "independent" negotiator Martti Ahtisaari, who claimed, five years after Dayton, that 300,000 people were killed in Bosnia and Herzegovina, ${ }^{25}$ and that facts prove that the war in Bosnia and Herzegovina claimed somewhat less than one hundred thousand $(96,000)$ victims (dead and missing) - on all three warring sides, ${ }^{26}$ but that after comparing the numbers of the dead and missing to the ethnic structure of the population before the war, it was proved that the majority killed were Muslim while Croats had the least victims. Furthermore, during the bombing, many USA officials claimed that the Serbs killed 100,000, or 250,000 or even half a million Albanians. "Gradually, the number was reduced to 11,000 , and remained there despite the fact that only 4,000 bodies were found in one of the most intensive searches in the history of forensic medicine, without it being discovered how many of those bodies were Serbian soldiers and civilian victims of the NATO bombing. But, those 11,000 must be valid if the NATO and the ICTY say so; which is why Michael Ignatieff assured the readers of the New York Times (November 21, 1999) that 'whether the 11,334 bodies will be found depends on whether the Serbian army and the police removed them'. ${ }^{27}$ By using such militant rhetoric, the Western officials added fuel to the fire all along, from the first day of the crisis, and more knowingly than not, i.e. they instigated violence for the purpose of achieving their own interests. And all the while, they have been declaring hypocritically that they acted to alleviate it.

As the crisis worsened, justifying the upcoming actions against the Serbs or spreading anti-Serbian propaganda was taken to the next level. The Serbs had to be portrayed as morally Evil, and all means were allowed against the morally Evil, i.e. actions against them could easily be justified before the public; also, the propaganda machine ensured beforehand, or subsequently, wide support for any action against them. In this way, all obstacles were eliminated before any action was undertaken, and all the participants were relieved of any legal or moral responsibility. That is why Bill Clinton claimed that "the Serbs are terrorizing and raping Albanian children"28; Jacques Chirac, the president of France, claimed that the Serbs are people without "law or any set of beliefs, they are thugs and terrorists",29;

${ }^{25}$ Ahtisari, M. (2001), Misija u Beogradu, „Filip Višnjić“, Belgrade, p. 27 [Ahtisaari, M. (2000), Tehtävä Belgradissa, Werner söderström osakeytiö, Helsinki]

${ }^{26}$ The Research and Documentation Centre, Sarajevo

(http://www.roaringpenguin.com/mimedefang/enduser.php3). In an interview given to B92, the president of the Research and Documentation Centre for the victims in Sarajevo, Mirsad Tokača, declared that there were 97,207 victims in Bosnia and Herzegovina on all three sides, B92, June 21, 2007

${ }^{27}$ Herman, S. E. (2006), „The Approved Narrative of Srebrenica Massacre“, pp. 418

${ }^{28}$ See internet address: 5Govor78+povodom5o.godišiceNATO-a45\{Wašington

${ }^{29}$ Petrović Piroćanac, Z. (1999), p. 11-112; also: Kuper, D. (1998), [„Kolektivna odgovornost, 'moralna sreća' i pomirenje“"], Filozofski godišnjak, p. 11, 192 
to Madeleine Albright, American Secretary of State, the Serbs became "repulsive" while to Richard Holbrook, an American diplomat, they were "dumb-ass criminals". ${ }^{30}$ German chancellor Helmut Kohl declared that "the Serbs can suffocate in their own stench", while an American congressman David Obey declared that "the Serbs are pigs" ${ }^{31}$ The description attributed to the Serbs was used in Austria before World War I. ${ }^{32}$ Many churches in Germany were decorated with Judensow sculptures as a symbol of the humiliation of the Jews, ${ }^{33}$ while the favourite term for the Jews in the Nazi Germany was "pig" and Sowjuden /"Jewish pig"/, ${ }^{34}$ the culmination of which was the holocaust, as we all know. Laurent Fabius, then Head of the parliament of France, declared that "the Serbs are garbage". ${ }^{35}$ Warren Christopher, former US secretary of foreign affairs, called the Serbs "an immoral race"; an American senator, Joseph Biden, said that the Serbs are "baby killers"36, while according to a Polish diplomat, Tadeusz Mazowiecki, a subsequent "independent" reporter on the state of human rights in Bosnia and Herzegovina, who did not wish to fall behind the statements of his masters, sexual violence became "a part of the ethnic cleansing conducted by the Serbs". ${ }^{37}$ In the next stage, Bill Clinton compared the Serbian government to the government of Nazi Germany in his speech on Memory Day in 1999, in an effort to justify the bombing of Serbia. He declared on that occasion that "a parallel can be drawn between Kosovo and World War II, because the authorities in Serbia just like those in Nazi Germany, prospered by influencing the people to see certain races or ethnic groups as

${ }^{30}$ Petrović Piroćanac, Z. (1999), p. 11-112

31 William Dorich, A Pompous Academic Ass, American Srbobran, May 17, 1999 (http://members.tripod.com/ sarant_2/ks23dorich.html)

32 Зундхаусен, Х. (2008), Историја Србије од 19. до 21. века, Klio, Belgrade, p. 247[Sundhaussen H. (2007), Geschichte Serbiens 19. - 21. Juhrhundert, Bö Verlag Ges. M.b. H und Co. KG, Wien - Köln - Weimar]

${ }^{33}$ Buruma, J. (2002), Plata za krivicu, Samizdat, Belgrade, B92, p. 195 [Buruma, I. (1995), Wages of Guilt, Vintage, London]

${ }^{34}$ Animosity towards the Jews has had a long tradition in Germany. Even Luther (Martin Luther, 1483-1546) was explicit in saying that "death would be his final solution for the 'Jewish issue"”. Hegel (Georg Wilhelm Friedrich von Hegel, 1770-1831) believed that the Jews could not be assimilated into the German culture because greed makes them follow thier ,animal existence“, while Wagner (Richard Wagner, 1813-1883) wrote that „the Jewish people were 'born enemies of the humanity' and that they pollute German culture like 'parasites in a corpse'" - Peterson, C. (2007), Večna Treblinka: Naš odnos prema životinjama i holokaust, Dobar naslov, Belgrade, p. 53-54 [Patterson, Ch. (2002), Eternal Treblinka. Our Tretment of Animals and the Holocaust, Lantern Books, New York]

${ }^{35}$ Petrović Piroćanac, Z. (1999), p. 11-112

${ }^{36}$ Kon, M. (2000), „Ne-humanitarna oružana intervencija Sjedinjenih Država i NATO-a kao prekršaj međunarodnog prava“, Filozofski godišnjak, p. 13, 326

${ }^{37}$ Espresso, February 28, 1993 
S. Vukovic, Media and Officials - A Negative Simbiosis during the Yugoslav Crisis in the 1990s

inferior, and to believe that those have no place in their country, much less the right to live there". 38

In order to avoid the legitimacy of German participation in the bombing of Serbia form being disputed and questioned, and to subsequently gain wide support of both the German and international public for it, Gerhard Schröder later declared that anyone in Germany who objected to the imposed paradigm that the Serbs are the criminals and the Albanians the victims was a "fifth columnist". That way, he tried to avoid the established pattern on one hand, and the issue of German responsibility on the other, to be called into question. (To make the paradox even greater, Schröder was engaged by the Democratic Party twice in election campaigns in Serbia and he gave public speeches at the rallies!) Therefore, a wide consensus was achieved regarding who was the innocent victim and who the criminal, and this is entirely confirmed by the statement of Joseph Fisher - he said that all those opposing this paradigm where nothing other than "supporters of fascism". 39

The cited descriptions attributed to the Serbs (and to other nations in the Balkans in the past, whenever their actions did not suit any of the great western powers ${ }^{40}$ ) and allegations made at their expense were not isolated opinions of individuals or their incidental statements, but a constant platform based on which the "long-lasting" European political elite (Brodel) evaluates nations, which was later accepted by the American political elite in the last decade of the $20^{\text {th }}$ century. In this way, the Serbs as a small nation (as often happens with small nations), and the subsequent actions against them, could be put out of the reach of even the slightest legal protection or moral obligation. Francis Jennings believes that calling someone savage, animal or by any other name "means issuing a warrant for his death and leaving him unknown and unlamented". "Naturally, this is not done out of a particular hatred towards the Serbs, but for the purpose of legitimizing their own interests more easily, i.e. to initiate and then justify their own participation in the break-up of the second Yugoslavia caused by the war; to subsequently legitimize the NATO bombing of Serbia and, ultimately, to implement and justify the American (and European), at first concealed and then public support to the secession of Kosovo and Metohia from Serbia (the promised independence the

${ }^{38}$ See: Džonston D. (2005), [Suludi krstaši], p. 24

${ }^{39}$ Kuenzel, Mithias (2000), Der Weg in den Krieg: Deutschland, NATO und das Kosovo, Berlin; cited by: Mitić, M. (2005), Nemački pogled na jugoslovensku krizu, author's edition, Belgrade, p. 111

40 The British prime minister Lord Beaconsfield (Disraeli) called the Romanians "infamous" and "Romanian scoundrels" after they joined in the war against Turkey in 1877 Ković, M. (2007), Dizraeli i istočno pitanje, Klio, Belgrade, p. 47

${ }^{41}$ Fisher, E. (1979), Women's Creation: Sexual Evolution and the Shaping of Society, New York, Doubleday, p. 190; cited in: Peterson, Č. (2007), [Večna Treblinka: Naš odnos prema životinjama i holokaust], p. 44 
Kosovo the Albanians spoke of all along). At the same time, they tried to obtain a form of retroactive consent for their actions; by making concessions and promises, and offering support in parliamentary elections to one part of the political elite in Serbia; and by threats in case the other part of the elite (the uncooperative or less cooperative part) should come to power. All this was presented in the propaganda rhetoric as acting for the good of Serbia, in accordance with the old paternalistic principle of those in power. This implies that the means used against the country and its citizens (isolation, banishment of the Serbs from Croatia and from Kosovo and Metohia, bombing) were justified - even the forced expropriation of a part of its territory. All that is missing is the phrase which ultimately ensues from such concepts of "justice" - we have been bombing and killing you for your own good.

The latest statement of Daniel Fried, assistant to the US secretary of state, confirms the fact that this has been the long-term policy of the American administration with regard to the Serbs (or it can be interpreted in that context). After more than seven years - and countless statements of American officials about friendship with the Serbian people (made in order to disguise things), in which the SerbianAmerican alliance in two world wars was evoked - he called the Yugoslav (Serbian) army from the time of NATO aggression against Serbia "predatory armies",42 in order to justify the secession of Kosovo and Metohija. Several questions inevitably arise. First, can an army defending the territorial integrity of its country be so named? Second, can an army fighting against a terrorist organization, the KLA (as termed by American officials on several occasions) be called that? Third, what do you then call the American army which waged wars in Vietnam and elsewhere across the planet and now in Afghanistan and Iraq? And, fourth, what do you call an army which holds prisoners without any legal grounds and with no legal protection? (Just the list of all the crimes committed by the American army could not fit into a comprehensive book.)

Such and similar accusations, lies and labels at the expense of the Serbs (and Serbia) can be heard to this very day. The minute the slightest crisis in the Balkans appears, or when Serbs refuse utter obedience, a campaign is launched against them in order to subdue them. Making the Serbs look bad, i.e. saying something bad about them was a matter of political prestige among the Euro-American officials. Few were those who refused to participate in that contest, because that would have meant they were not going with the tide. And confronting the tide, ever so slightly is disadvantageous to the career.

The demonization of the Serbs took on incredible proportions among the journalistic and political elite. After various stock phrases were exhausted -"Serbia enjoys playing the part of the martyr in Yugoslavia" 43 for example, the main

${ }^{42}$ R. McMahon's interview with Daniel Fried for an internet publication of the Council of foreign affairs (http://www.cfr.org/publication/12563); also: Политика, February 8, 2007.

${ }^{43}$ Le Monde, October 9,1991. 
S. Vukovic, Media and Officials - A Negative Simbiosis during the Yugoslav Crisis in the 1990s

purpose of which was to refute and ridicule any objections to the reporting of the Euro-American media and the moves of their officials against legitimate Serbian interests - more severe accusations were made. This is why it came as no surprise that the Serbs were charged with terrorism. On February 26, 1993, after the explosion at the World Trade Centre, Anthony Lake, Clinton's security adviser, asked - "Was it the Serbs? Did the Serbs place the bomb?"44 After the assassination at the Saint-Michel underground station in Paris on July 25, 1995, Jean-Louis Debré, the minister of foreign affairs, immediately recognised a "Serbian connection" ${ }^{\text {" }}$. The following day, inspired by this statement, Michael Binyon wrote in The Times that, "the bomb in the underground railway raises fears of Serbian terror against France". ${ }^{46}$ The Italian Il Giornale claimed at the same time that, "experts blame the Serbian Black Hand" 47 for the action. In his first public response, the president of France at the time, Jacques Chirac, blamed two groups with a strong motive - Bosnian Serbs and those opposing nuclear research. A while later, after the attack on World Trade Centre on September 11, 2001, the first news was that the Serbs had done it, and after the terrorist attack in London on July 7, 2005 it was first said that the explosives came from Belgrade, not to mention the myriad of films made in the West, some of which were broadcast on Serbian national television, and in which the Serbs were portrayed as the bad guys and often even as terrorists. The propaganda lie that "Serbian terrorists" were allegedly planning assassinations all over Germany - that of the president of the FDP, Otto Graf Lambdsdorff, and the CSU parlaiment member, Otto von Habsburg - was launched by the German media, assisted by officials, just as was the case with many other false allegations. That last allegation was made by Carl B. Buchalla in the liberal Süddeutsche Zeitung from Munich in reporting the statement of the Federal Crime Bureau (BKA) at the peak of the anti-Serbian campaign in Germany and the final preparations Germany was making to break up the second Yugoslavia (recognizing the republics in the north-west). ${ }^{48}$ The fact that this was not an isolated case is confirmed by a text published a week later in the respectable Der Speigel, claiming that "nearly all the 700 Germans living in Serbia receive death threats and anonymous telephone calls", ${ }^{49}$ which was a downright lie, as in many similar situations.

${ }^{44}$ Clarce, A. Richard (2004), Against All Enemies, Hamburg, p. 106; cited in: Elzeser, J. (2006), Džihad na Balkanu: Kako je džihad stigao u Evropu, Jasen, Belgrade, p. 48 [Elsässer, J. (2005), Wie der Dschihad nacsh Europa kam Gotteskriger und Geheimdienste auf dem Balkan, Pöten-Wien-Linz]

${ }^{45}$ Bario, P. - Krepen, E. (2007), Suđenje Miloševiću ili optužba srpskog naroda, IhitusHrišćanska knjiga, Belgrade p. 79

${ }^{46}$ The Times, July 26, 1995.

${ }^{47}$ Il Giornale, July 26, 1995.

${ }^{48}$ Süddeutsche Zeitung, November 30, 1991.

${ }^{49}$ Der Spiegel, December 9, 1991. 
Creators and leaders of public opinion in the West used these incredible allegations and descriptions, if not to surpass, then at least not to fall behind their politicians in defaming, condemning and inventing lies about the Serbian people. They seemed to be competing in who could make the Serbs look worse and who would invent a new lie about them - or perhaps they acted as an incentive to each other in the matter. Some of these false stories (by the American journalists Roy Gutman and John Burns) even gained the Pulitzer Prize for journalism in 1993, rather than receiving the moral condemnation from members of the professional community which they so richly deserved. ${ }^{50}$ All of this discouraged the representatives of the media who believed that telling the truth is in the interest of the public, as Dale Jacquette put it. ${ }^{51}$ Based on a conversation with the Muslim refugees in Zagreb (without having set foot on the scene), Gutman published a story "from the scene of events", just before the negotiations in London, claiming that the Serbs were running "death camps", thus violating the ethical rule about verifying the accuracy of information with two independent sources, which is meant to guarantee the validity and reliability of the news. Gutman's story stated that "Serbian conquerors were running two concentration camps in which more than a thousand civilians were executed or starved to death, while several thousands were left there to die". Moreover, "armed Serbian guards led prisoners in groups of 10-15 to be executed every day"; already "1,350 people have been killed and tortured near Brčko from May 15 until mid June", "most of which had their throats slit", "bodies were burnt in crematoriums and turned into cattle feed", etc. ${ }^{52}$ He violated his moral duty to tell (the relative) truth by doing this, which was a common case with the Euro-American reporters when it came to reporting on events in the second Yugoslavia.

Immediately after this story was published, European and American media began equating the Serbs with the Nazis, as if by order. Thus, the reputable New York Times in its editorial accused the Serbs of "ethnic cleansing", "concentration camps" and creating a "Greater Serbia"; in order to corroborate all that "analytically", it said that "Serbian misdeeds parallel those of Nazi Germany". ${ }^{3}$ Almost at the same time, the journalist John Barns of the New York Times interviewed Borislav Erak, a mentally ill Serb from Bosnia and Herzegovina, and described him as a prototype of "a bloodthirsty Serb". The wretched Erak said in the interview that Lewis Mackenzie, the commander of UNPROFOR at the time had raped many Muslim women, in order to disqualify him, which Barns happily

\footnotetext{
${ }^{50}$ Marxism, Mars 1993; Collon, M., [,,Medijske laži o Srbima: Šta treba da se sakrije?“], published in: Medijski rat protiv Srba (1995), sellection of texts by Ž. Ivanović, Belgrade, p. 21, 22

${ }^{51}$ Žeket, D. (2007), Novinarsk etika: moralna odgovornost u medjima, Službeni glasnik, Belgrade [Jacquette, D. (2007), Jurnalistic ethich: moral reponsibility in the media, New Jersey]

${ }^{52}$ New York Newsday, August 2, 1992.

${ }^{53}$ The New York Times, August 4, 1992
} 
S. Vukovic, Media and Officials - A Negative Simbiosis during the Yugoslav Crisis in the 1990s

reports. ${ }^{54}$ Many versions of these two stories were published in all the important print media of Europe and America, and were broadcast for days on radio and TV stations. Naturally, these were not the only stories of American or European journalists based on semi-truths, lies and unverified information. Whether the publisher denied their content depended on the power of the injured (or "injured") party, on whether it was in the actual or fictional interest of the nation, etc. ${ }^{55}$ However, regardless of the potential (subsequent) disclaimers, the damage is irreparable.

There was another instance when the attempt to deny a false story was condemned to failure. The London magazine $L M$ was sentenced to pay damages for an article by the journalist Thomas Deichmann, in which he proved that, in the summer of 1992, the crew of the London television ITN, in chasing sensations and demonizing Serbs, "showed" the image of "a concentration camp"; the image was constructed when the TV crew lead by Penny Marshall, and accompanied by cameraman Jeremy Irving and a reporter of The Guardian, Ed Vulliamy, ${ }^{56}$ walked into a fenced-in area and filmed the people standing outside the barbed wire as though they were in a camp. (It was a refugee centre in Trnopolje from which the "prisoners" were free to leave at will.) ${ }^{57}$ They shot Fikret Abdić, a skinny allegedly starved boy behind the barbed wire as if he were in the camp (it was actually a Serb, Slobodan Konjević, who had tuberculosis), and that was used as the crowning "evidence" that the Serbs had set up "death camps" resembling Nazi camps. That image was broadcast for days on all main TV stations in the world, with the help of the agency Rder \& Finn, and it was accompanied by all sorts of fabrications and allegations at the expense of Serbs. The story was published on the front pages of the newspapers with the highest circulation. A court in Great Britain acknowledged that the ITN reporters had been libelled since Deichmann claimed

\footnotetext{
${ }^{54}$ The New York Times, January 9, 1993; also: Piter Brok (1995), „Huškaško novinarstvo“, in: Srbija mora umreti, p. 24; Džonston, D. (2005), [Suludi krstaši], p. 141

55 At the beginning of May 2005, the weekly magazine Newsweek published a story describing the brutal methods of the American army in the military base of Guantanamo in Cuba, saying that soldiers desecrated the copies of the holy book of Kur'an by putting them on toilets, and that they even threw a book into a toilet once. The story caused bloody antiAmerican protests in the Islamic world. The American Headquarters issued the following statement on May 16: "We have been unable to discover anything to support the allegations which appeared in Newsweek". Two weeks after the story was published (on May 23), Newsweek was forced by the anti-American protests and the American Headquarters to withdraw the story on Guantanamo - Žeket, D. (2007), [Novinarsk etika: moralna odgovornost u medjima], p. 36-42

${ }^{56}$ It is a reporter who wrote the following during the war in Bosnia and Herzegovina: "My father had the honour to fight against fascism; I, however, have the strange privilege to meet people who fight against a pale but unmistakable imitation of the Third Reich" The Guardian, April 10, 1993; cited by: Hjum, M. (2001), „Nacifikovanje Srba, od Bosne do Kosova“, u: [Degradirana moć], p. 128

${ }^{57}$ Deichmann, T., „,The Oicture That Fooled the World“, Living Marxism, February 1997
} 
that they had done it intentionally. The British court did not judge the veracity of Deichmann's story. ( $L M$ lost the lawsuit because of the controversial British law on libel, which is often used to restrain the freedom of the press.) Judge Morland specifically said that he had the impression that the wire surrounded the reporters and not the camp, but he added that he dared not judge whether the reporters had done it intentionally and thus tried to deceive the public (which goes against the basic principles of the ethics of journalism). The consequence of the verdict was far-reaching - no media in England dared publish Deichmann's story ${ }^{58}$ and the magazine $L M$ was financially ruined (it was sentenced to pay damages of one million pounds), which were the essential goals of the court verdict. ${ }^{59}$

There is an impression that many Western, not only officials but journalists as well, competed in defaming and accusing the Serbs. This was done for several reasons - ideological misconceptions, old and new prejudice, adopted stereotypes, easier advancement on the hierarchy ladder, the venality of both (with ranks, privileges, etc.), and last but not least, it was done in order, first publicly and then morally, to justify and ultimately conceal the role of the Western governments, i.e. their tolerance of the German command which was crucial in breaking up the second Yugoslavia, the consequence of which was the beginning of the war. German philosopher Klaus Theweleit put it like this- "As for Genscher's stunt with recognizing Slovenia, all I could think of was 'This means war in the Balkans, and a real war. Why can't you, idiots, see that?",60 The problem was that the German political elite saw that very well - it needed a war in the Balkans, which is why it was so insistent on recognizing Slovenia and Croatia. According to Yohanan Ramat, head of the Israeli Institute of Defence in Jerusalem, the same was done with the Czechs in 1937 and 1938, in an effort to justify Chamberlain's policy (Arthur Neville Chamberlain, 1869-1940) and the secession of the Sudeten area from Czechoslovakia and its annexation to Nazi Germany. He emphasized that the primary goal of the Western policy towards Yugoslavia was not "to create new countries by applying the principle of ethnical affiliation (...) but to destroy Serbia and eliminate its influence on the Balkan Peninsula". ${ }^{61}$ This hypothesis, made in 1992 was largely confirmed by subsequent events - sanctions, the bombing of the Bosnian Serbs and then the Republic of Srpska Krajina and finally Serbia, NATO occupation of Kosovo and Metohija, the secession of Montenegro from Serbia

${ }^{58}$ Vidi: Beham, M. (2004), „Govor mržnje u politici i medijima“, u: Etika javne reči, edited by Z. Vacić, CLDS, Belgrade, p. 168; also: Alterman, Eric, „Bosnia Camps: A Barbed Tale“, The Nation, July-August, 1997, p. 19

${ }^{59}$ This fact also casts doubt on the objectivity and impartiality of the British judicial system (which is promoted in the entire world by the British official as an example of independent judicial system), particularly when British "national interests" are concerned.

60 Klaus Theweleit, „Über die 68er“, Konkret, Mai 1999 (http://www.servus.at/ka$\mathrm{nal} /$ nato/68er.htm); published in НИН, June 12, 2008

${ }^{61}$ Ramati, Y. (1992), „Who killed Yugoslavia?“, Midstream, XXXVIII, No. 9, p. 4. 
S. Vukovic, Media and Officials - A Negative Simbiosis during the Yugoslav Crisis in the 1990s

(which Britain promoted even at the congress in Berlin), the latest constant coercions by the USA and European Union. The Western media, fully supportive of the foreign policy of their governments, prepared and made allegations against Serbs and Serbia before the world as if by order, in order to achieve the mentioned goals.

In modern times, such a method was tested during the war for the Malvinas (Falkland Islands) when Margaret Thatcher, then British prime minister, chose which reporters would board the ships and decided where they would be taken and what would be shown to them and it was even suggested how they should write their reports. On that occasion, a silence pact, or some sort of "patriotic" autocensorship, was formed between the government and the representatives of the press ${ }^{62}$ something which had already been done during the Crimea war and the Great eastern crisis from 1875-1878.

A similar thing was done during Desert Storm. The journalists did not have free access to the scene of events; they published what they were served by the American command; it was determined in advance who the culprit was and who the innocent victim, and for that purpose the public was bombed daily with shocking fabricated news. There is an example illustrating this. The agency Hill \& Knowlton, hired (paid) by the American government to paint a picture of Kuwait during the Gulf War in 1990, hired a fifteen-year-old girl to testify before the American Congress that she had seen the Iraqis shut down the power in the incubators in a hospital in Kuwait City, which caused many premature babies to die. The news went worldwide in an instant, and was used as an excuse for America to bomb Iraq. It later turned out, after the deed was done and after many forgot about the testimony, that the girl had testified falsely, that she was the daughter of the then Kuwait ambassador to the United Nations, and that she had not been in Kuwait for who knows how long. ${ }^{63}$

This has been repeated, directly or indirectly, in many other cases all over the world in which the Western powers have been involved, particularly during the Second Gulf War in Iraq when 700 American and British journalists joined the military units following a decision of the American army from February 2003 (journalists from other countries were not allowed). A document from the Pentagon stated that they would "substantially shape public opinion about national safety today and in the years to come", thus referring to the public in the USA, the public in allied countries and the countries in which operations are being conducted, and "whose sentiment could affect the stability of our coalition"; it also says that "our story needs to be told by our people". However, just in case, for their own "safety", the journalists and "the media were not allowed to use their own means of

${ }^{62}$ Remondino, E. (2002), Televizija ide u rat, Clio, Belgrade, p. 11-13 [Remondino, E. (2002), La televisione va alla guerra, RAI-Eri i Sperling \& Kupfer, Milano]

${ }^{63}$ Merlino, Ž. (1994), Istine o Jugoslaviji nisu sve za priču, Kontekst, Belgrade, p. 98 [Merlino, J. (1993), Les Vérités yugoislaves ne sont pas toutes bonnes à dire, Albin Michel, S. A., Paris]. 
transportation", with a note that "unit commanders can impose temporary restraints on electronic broadcasting", etc. ${ }^{64}$, and they were allowed to see and report only what the army prepared or approved. That way, the journalist became only a part of the propaganda machinery. Later on, they justified their consent to this as a "oncein-a-lifetime experience", "being better informed", "seeing war from the angle of the common soldier", etc.

During the war in Bosnia and Herzegovina, the established pattern was repeated, i.e. the Western media systematically implemented the policy of their governments and "classified the killed people as Croats or Muslims from Bosnia and Herzegovina". "In most cases, the families of those unfortunate people identified them - they were Serbs killed by Croats, and sometimes Muslims". ${ }^{65}$ The majority of the Western media refused to publish information coming from Belgrade under the excuse that it was biased. On the other hand, the information from Croatian and Muslim sources, and later from Albanian sources, was not "biased" because it conformed to the established pattern or to the image officials requested. One of hundreds of examples of misinformatio is the case which occurred at the beginning of the war in Bosnia and Herzegovina. The Italian newspapers Il Manifesto published that Associated Press had sent them a heap of photographs from the site. Among them there was a photograph of a woman holding a child in her arms, and the child had a toy gun in his hand. The writing under the photograph said - "Bijeljina, Bosnia and Herzegovina, May 21. Refugees. A Serbian child, Marko Djurić, who found refuge in the village Crno Blato, is playing with his gun in the arms of his grandmother". The photograph was published on the front page of Il Manifesto, with the writing under it. The same photograph was published by La Stampa under the following caption - "A child's toy-gun for the little Croatian refugee", while the communist paper L'Unita published the photograph with the news that "Serbian militia stopped a convoy of refugees from Bosnia". ${ }^{66}$ The Italian journals flagrantly violated basic moral principles and the principles of their ethical code without any moral or legal repercussions. ${ }^{67} C N N$ did a similar thing when Christiane Amanpour reported from a funeral of two Muslim babies, as she claimed, who were killed by Serbian snipers, when the truth was quite the opposite

${ }^{64}$ Memorandum $101900 Z$ of the Minister of Defence (OASD-PA) from February 2003; cited by: Žaket, D. (2007), Novinarska etika, p. 302-312; see also: Katorsky, B. and Carlson, T. (2003), Embeded: The Media at War in Iraq, Lyons Press, Guilford.

${ }^{65}$ Defence \& Foreign Affairs - Strategic Policy (1992), Vol. XX, no. 12, p. 6

${ }^{66}$ Il Manifesto, May 23, 1992; cited in: Medijski rat protiv Srba (1995), sellection of texts by Ivanović, Ž., Belgrade, p. 224-225

${ }^{67}$ The ethical code of the Society of Professional Journalists states that "the content of photographs and videos must never be doctored" - see: http:// www.spj.org; cited in: Žaket, D., 2007, [Novinarska etika: moralna odgovornost u medijima], p. 389-393 
S. Vukovic, Media and Officials - A Negative Simbiosis during the Yugoslav Crisis in the 1990s

- they were Serbian babies killed by Muslim snipers. ${ }^{68}$ This journalist did the same thing on several occasions, including when she reported on the situation in Kosovo and Metohija during the NATO bombing, because such reporting suited NATO propaganda (justifying the bombing) and was better accepted, if not the only kind the Western media accepted. Dozens of these and similar lies (and violation of journalistic ethics) which the Euro-American journalistic elite published about the events in the second Yugoslavia at the beginning of the 1990s will be mentioned in the course of this study. This is a common practise with western journalists when others are concerned - since there are no sanctions for it, and it can even be rewarded - which means that honouring the truths ranks very lowly.

Finally, "Serbian crimes" are represented in the public discourse as institutionalized facts which the media manipulation of the public presents as natural facts that require no proof. And that is why the individuals who call them into question must be excommunicated.

\section{Слободан Вуковић}

Резиме

Институт друштвених наука

Београд

\section{УЗАЈАМНА ЗАВИСНОСТ МЕДИЈА И ЗВАНИЧНИКА: ЈУГОСЛОВЕНСКА КРИЗА 1990-ТИХ}

У тексту се анализира наметнута парадигма у западним медијима о југословенској кризи. Упоредном анализом показујесе узајамни утицај између изјава званичника и писања медија. Како се криза заоштравала оптужбе на рачун Срба су се из дана у дан умножавале како би се на моралном плану представили као Зло. Срби су за једне свиње и ђубре, за друге злочиначки дупеглавци, а за треће народ без вере и закона. У следећем кораку они су оптужени за тероризам и фашизам, да би се убрзо прешло на претњу да ће Србија клечати на коленима и молити за милост, а затим да је треба претворити у прах и пепео.

Све ове оптужбе, епитети и претње биле су у функцији оправдања разбијања друге Југославије и како би се у њеном разбиању минимизирала улога Запада. У том послу међу западном политичком и новинарском елитом постигнута је широка сагласност. Оптужба на рачун Срба и Србије била је ствар престижа - једни су напредовали на хијерархијској скали положаја а други награђивани престижним наградама.

Кључне речи: Срби, Србија, Запад, медији, званичници, епитети, квалификације, претње.

${ }^{68}$ Gorin, J. „Remember Srebrenica - a.k.a. 'So what if we globalized al Qaeda!'“, Jewish World Review,

http://www.jewishworldreview.com/julia/gorin_2005_07_11.php3?printer_friendly 